\title{
Needs analysis of Islamic-based English reading material for the Muhammadiyah junior high school
}

\author{
Septian Dwi Cahyo, Muhammad Rijalul Umam Muslim, Arditya Nur Rahman, Bambang W Pratolo
}

Magister of English Education, Universitas Ahmad Dahlan, Indonesia

\begin{tabular}{l} 
Article Info \\
\hline Article history: \\
Received Mar 5, 2019 \\
Revised Apr 6, 2019 \\
Accepted Apr 20, 2019 \\
\hline
\end{tabular}

Keywords:

English language teaching Islamic education Material development Need analysis

\begin{abstract}
This research aimed to report the need for Islamic-based English teaching materials for the Muhammadiyah junior high Schools, specified for reading skill. Data collection techniques in this research were the semi-structured interview and focus group discussion with four English teachers as participant form the Muhammadiyah schools. Data analysis was conducted by interactive data collection, data reduction, data presentation and conclusion or verification. This research concluded that the needs of developing Islamic based English teaching material are necessary for the Muhamamadiyah schools to achieve the national education goal and for Islamic faith itself. The development based on text-based approach by replacing content with Islamic-related content, Islamic discourse, integrated language skill, use student-centered teaching and also increasing cultural awareness.
\end{abstract}

Copyright (C) 2019 Institute of Advanced Engineering and Science. All rights reserved.

\section{Corresponding Author:}

Bambang W Pratolo, English Graduate Program, Universitas Ahmad Dahlan, Pramuka street 42, Umbulharjo, Yogyakarta, Indonesia.

Email: bambang.pratolo@pbi.uad.ac.id

\section{INTRODUCTION}

Today's Indonesia education concern on students' character development. Strengthening literacy culture is related to readings and literary. The quantity and quality of readings also provide characters education for students. Thus, integrative reading materials in English language teaching can be an option to cover the globalization requirement, skill to communicate as a global citizen, and strengthening literacy culture and also give character education by providing reading material embedded with Islamic discourse as replacement of western liberal views. The Globalization derives secularism of knowledge which became a problem since in the era of Early Islam civilization resulting in a crisis of leadership [1,2]. Baytiyeh points out the globalization has threat some Muslim to be resistance since Islam has been taught as a subject not to be integrated into science [3].

Integrating Islamic values into the subject is the answer to the social education problems of secularism within Islam. According to al-Shaybaniy, Islamic discourse has several concepts for education [4], to produce a pious human being who is devoted to God, to carry out lifelong learning, to develop the total potential of a person's soul, mind and body in an integrated way, to develop a person's capability to carry out his duties as a servant of God and as a "Khalifah" of God (representative or vicegerent of God on earth)

Al-Shaybaniy stated an Integrated Islamic Education focuses mainly on implementing Islam as a whole. This can be done by integrating Islamic knowledge and belief, matching the belief and practice, balancing the work for "worldly affairs" and the religious duties for the hereafter. Through the Integrated Islamic Education, a person can be educated and trained to understand and uphold the Islamic faith, the laws and the morals in one's life [4]. 
Islamic integrated education is based on akhlak (morals, ethics) as a result and objective of education. akhlak is the terms for behavior based on value, virtue morals represent on the personal act. In the context of education, akhlak is the things to be instilled to students, therefore it also the education goals. The goals also known as achievement is divided into cognitive, affective and psychomotor. Each of the three components should support the creation of akhlak of a human being or student as represented by Figure 1 [4].

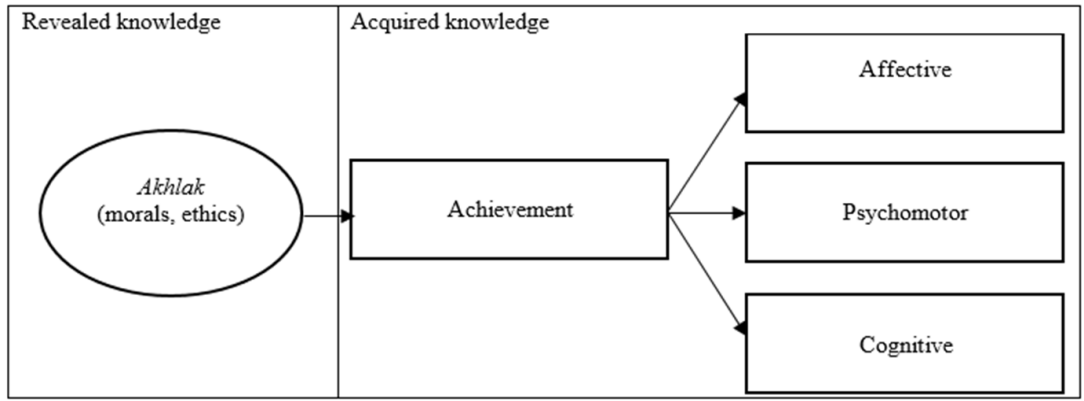

Figure 1. Islamic concept and education objective concept

Those concepts are in line with the Indonesia National Education Goals. Thus, integrating Islamic values into education. The result of the integration can be used as a concept for preventing unwanted negative globalization effects. According to Regulation Minister of Education National No. 22/2006 on Content Standards [5], it is explained that the purpose of learning English in Indonesia is directed for pupils in order to have the ability to develop competencies in the form of limited verbal communication to accompany the action in the context of school; tohave awareness of nature and the importance of English to increase the nation's competitiveness in a global society; and to develop students understanding the relevance between language and culture.

The national education goal demands each education element in the system to support in achieving the goal. Each subject also has to integrate characters as demanded by the curriculum; thus, the teaching is not only about knowledge but also morals and ethics by integrating the teaching and learning process. One of this integration can be done in developing teaching materials based on the values, morals, and ethics. The new material development is intended to overcome the current materials which often to generals the material development should not be random, it should consider the needs. The teaching should meet the needs and wants of the learners [6]. The development consideration is the theories of language acquisition and development, principles of teaching, the use of the target language, evaluation of current use material.

Islamic-integrated Education has the main problem, it is the number of the limited resource of Islamic-integrated reading materials. Teachers take teaching resources from a common textbook in the market. The quality is standardized but often not suitable for enhancing Islamic discourse and values, especially if the textbook is used by madrasah or Islamic based school. Considering the number of Muslim and Islamic based school in Indonesia, developing a textbook based on Islamic discourse and values is necessary. The textbook supports both Islamic based school and national education goals. This article provides a need analysis of developing English language teaching reading materials embedded with Islamic discourses and values. Reading is the most common materials in classroom activities and can be independently studied by a student in their time outside the classroom. The materials will provide readings for students which also help students to learn English and integrating Islamic values. The notion of al-Qur'an as the basis of all branches of knowledge including linguistics and language pedagogy could be a stimulating point of departure [2].

Fairclough on Abdollahzadeh argues that "language connects with the social entity through being the primary domain of ideology, and through being both a site of and a stake in, struggles of power." Students need to acquire English to live as global citizens [7]. Khosravani et al. reported that leadership life skills, critical thinking life skills, and decision making/problem-solving life skills often not included in the textbook or English teaching materials [8]. Therefore, need analysis needs to be conducted to accomplish the needs of each element regarding teaching English in Islamic education.

Muhsinin et al. reported that reading materials designed based on Islamic values for higher students increasing students' reading comprehension [9]. The syllabus is designed based on the need to create a reading material which is far from western culture, including Islamic values and culture and also considering the background of students' need in the Islamic education department.

Need analysis of Islamic-based English reading material for the Muhammadiyah ... (Septian Dwi Cahyo) 
Umam reported a necessity to maintain Islamic value in English language teaching in Pesantren, an Islamic based school [10]. The challenges to face globalization and Asean Economic Community require the student to have "identity", ideology, concept and values in order to survive and to gain a significant role in the community. The maintenance is done by creating some policies in the internal institution; Optimizing the Use of instructional materials containing Islamic messages; Using carefully selected textbook which is supporting the idea of integrating Islamic messages and values but there is no textbook as mentioned, and the writer recommends ministry of religious affair to develop the textbook; promoting to use Islamic value based authentic materials, and enhancing teachers to have multi-qualification in Islamic knowledge and English language teaching.

Faridi, et al. criticized the narrative teaching materials in Indonesia which are the content of texts are not rooted in Indonesian culture [11]. As the readings affecting a person's perspective, the lack of cultural rooted narrative text lead to the weakening of national characters. The research promoted Islamic narrative text to be adopted in the teaching and learning process. The story about prophet, humor, and social life to help teachers implanting national characters and humanism.

Amri, et al. reported about the integrating Islamic value in education [12]. The results found that the policy, teaching methods, environment, stakeholders and teachers' control, and the evaluation were the dominant factors of the success of Islamic teaching due to the strict of reward and punishment applied by the school to rehearse the students' awareness earlier to be well behaved in a multiculturalist society.

Need analysis suggested for English language teaching by experts to create appropriate teaching materials for each education level. Sunengsih and Fahrurrozi conducted research to develop authentic materials for the elementary level [13]. The development results easier materials to understand for the students, since the authenticity make the English language teaching contextualized to students' world. Ulum reported a need for the development of speaking skill by using a questionnaire [14]. The report mentioned the necessity to have alternative materials which developed based on the need. The two reports a similar result in English language teaching, the need for materials which suitable for the level, thus it is essential to have sneed analysis.

Rohmah did an analysis of need analysis for Islamic based English language teaching materials for Madrasah, an Islamic based school also [15]. The research suggested that English language teaching materials based on Islamic values need to be developed by stakeholders. The textbook or materials should be fun for students, supporting materials for the national exam and enhance self-confidence among students.

Qamariah developed an instrument material based on Islamic value for teaching English at a school level [16]. The result shows that the English material used in the school still far from ideal to implement Islamic based teaching materials. The research suggested to give attention to the result of the assessment of the students' needs, combined with the institutional goals, and relevant to the curriculum of the study program. It is necessary for the teachers to be creative in implementing the developed material in the teaching and learning process. They should be able to facilitate the students with the atmosphere that encourage the students to be active in their learning, especially by bringing the simulated objects to the classroom or by using the real objects outside the classroom. For further development of materials, it is also advisable to do it on the basis of the students' major such as Natural Science, Social Science, and Language so that the terms and activities presented in the materials could be more specific.

English is unarguably important for the current era, the need to be a global citizen is mandatory. However, the problem of learning English or new language is the resistance of its secularism culture. As education is a process of instilling knowledge and culture into students, it is the agent of installing morals and value also. To prevent the secularism, negative culture of English, a material development based on intended culture is needed. Islamic value can be an alternative to be integrated into the teaching material since it is in line with Indonesia national education goals, further, the number of Islamic based school in Indonesia is massive. The lack of Islamic based materials or textbook in the market makes the implementation become irrelevant. Thus, developing a new material based on Islamic value is necessary. To be able to produce good material, need analysis is necessary to be conducted. This research is a report of need analysis to develop English materials based on Islamic value.

Teaching English as a Foreign Language, or TEFL, as it is most commonly referred, involves teaching English as a foreign language in countries where English is not the primary language. The Instruction of English as a foreign language may occur in any country, whether English speaking or not. Learners of EFL study English for different purposes: passing the examination, career development, pursuing their education, etc. In most countries, English as a Foreign Language is part of the educational curriculum, particularly in state schools. In Indonesia, English is a compulsory subject in senior and junior high schools.

Need analysis, also known as need assessment, is the process of determining the needs for which a learner or group of learners requires a language and arranging the needs according to priorities. Needs is the ability to comprehend and to produce the linguistic features of the target situation. A need analysis research

Int. J. Eval. \& Res. Educ. Vol. 8, No. 2, June 2019: 286 - 292 
shows to help teachers, curriculum developments, and syllabus design to bring English to be meaningful for students in their future [17].

Needs analysis makes use of both subjective and objective information (e.g. data from questionnaires, tests, interviews, observation) and seeks to obtain information on: the situations in which a language will be used (including who it will be used with), the objectives and purposes for which the language is needed, the types of communication that will be used (e.g. written, spoken, formal, informal), the level of proficiency that will be required.

Needs assessment is a part of curriculum development and is normally required before a syllabus can be developed for language teaching. There are 2 needs in language teaching;

a. Target needs, what the learners need to do in the target situation or in real-life conversation and condition. Target situation: the situation or setting in which the student will have to use the target language. This may be a study target situation or work situation or any context in which the learner needs to use the language. Analysis of the communicative and linguistic demands of the target situation is an essential phase in the needs analysis. There are three aspects on target needs; Necessities: what the learner has to know in order to function effectively in the target situation. Lacks the gap between necessities and what the learners have already known. Wants: what the learners want to know

During need analysis, this information can be gathered by using questionnaires, interview, observation, data collection, informal consultation. The information is related to the individual expectation of learning English, the linguistic features of the target situation (language items, skills, knowledge, etc.).

b. Learning needs, what the learners need to do in order to learn, standardized or based on the current curriculum of the program. This need is related to how learners need to do in order to learn. How the learners need to learn

There are many teaching sources for English language teaching, however the materials often not suitable for the cultural and idea of the learners. English is not free from the culture, which may lead to a conflict between English learner culture and English culture itself from the teaching materials. Thus, specified materials need to be developed to answer the conflict which may occur. This research intended to give an analysis of what kind of materials needed in the Muhammadiyah junior high school in English language teaching for reading skill.

\section{METHOD}

This research intended to report the result of need analysis of English language teaching reading materials integrated with Islamic value for the Muhammadiyah junior high school. This research includes qualitative research. Data are gathered by conducting a focused group discussion with English teachers who have thought at least 2 years of teaching experience in Islamic based school. Discussion summary and recording are used to document the discussion. Data analysis was conducted by interactive data collection, data reduction, data presentation and conclusion or verification.

In this study, the researchers interviewed Primary and Secondary Education Assemblies of the Muhammadiyah Regional Leader of Yogyakarta (Majelis Dikdasmen PWM DIY). The documentation used voice recorders and note taking. The type of the interview was the semi-structured interview in which some questions were prepared before interviewing and some additional questions were asked on the spot. The interview was used to collecting the qualitative data or confirmation toward what had been observed.

The teachers and stakeholders are chosen to be correspondent of this research considering their position who directly involved with curriculum and related education policies. Teachers also the one who understand the classrooms and the students which means they have valid information about what students' needs are. Stakeholders are well-known as they receive the policy from the government and have the right to order their institutions to or not to apply the policy based on their consideration of needs.

\section{RESULT AND DISCUSSION}

\subsection{Policy in the Muhammadiyah schools}

English subject in school is a mandatory subject for middle level, however, the Muhammadiyah has the policy to implement English subject for the elementary school as local content. The idea of implementation English subject at an earlier level is to prepare the students to face the future with their language and communication skills. The stakeholder is also aware of the opportunity of undesirable values which innate English. According to the Majelis Dikdasmen PWM DIY, it is the duty of teachers to integrate values within the English language teaching and other subjects

Need analysis of Islamic-based English reading material for the Muhammadiyah ... (Septian Dwi Cahyo) 
"...there needs to be integration, because after all the internationalization of language cannot be separated from political and western culture. So as much as possible teachers can provide knowledge not only skills in English but also our culture."

The Muhammadiyah points the need to teach English integrated with Indonesia culture and morals which means the teachers need to develop the English teaching materials integrated with morals, values, and culture in Indonesia. The problem with English subject in classroom activity is the materials are always taken from a book with a base of western's perspective, which most of the innate values are not acceptable in Indonesian culture. Further, the texts are often not authentic in the context of Indonesia socio-culture, geographic and philosophy.

Majelis Dikdasmen PWM DIY is developing a curriculum that combines the national curriculum and the Muhammadiyah curriculum. This curriculum integrates the noble values that are more detailed than the current Kurrikulum 2013. According to Majelis Dikdasmen PWM DIY, there are 3 models in developing material that is Islamic-loving; Islamization of science, Islamic as a science and moral and integrationinterconnection. Islamization of science is a perspective developed by Al Faruqi and Al Attas; Islamic as science was proposed by Kuntowijoyo, integration-interconnection was initiated by Amin Abdullah. Each approach is appropriate at a certain level of education, for the elementary and intermediate level the Islamization of science is more applicable. Islamization of science formed in 3 main approaches; labeling, axiology, and internalization [18]. The Islamization of science in English language teaching can be found in material development by providing Islamic based English text and discourse. For example, in the daily conversation teaching material, instead of providing an example of asking someone to join a birthday party it is better to give a conversation to ask someone to study or come to a study forum.

The problem with this concept is the limited number of Islamic text and discourse in English textbook and competence of English teachers to develop materials which deliver language function but integrated with Islamic teaching and values. The Muhammadiyah has a program to overcome the problems and also supporting the professional development of their teacher by providing a scholarship for master degree, a workshop for materials development and research funding for teachers;

\section{“... but we have to admit and realize that most of the teachers are not a modal (of materials development), thus professional development needs to be instilled to teachers"}

In order to enhance vocabulary mastery, the Muhammadiyah also demand their school to label schools' surrounding vocabulary with 3 languages; English, Arabic, and Bahasa and so the students will learn more vocabulary even when they are not in the classroom.

\subsection{English language teaching in the Muhammadiyah schools}

Islamic school implements the same curriculum for English language teaching; however, the headmaster and stakeholders have a policy for teachers to integrate Islamic values during the teaching and learning processes. The English learning has extra activity outside the classroom by providing an English day where everybody in the school speaks in English within once a week, however, the result of this policy is not meet the expectation, even though the students have improved their courage to speak in English.

The teachers should be a model for their students. The general Islamic values have the same essence with embedded characters in the national curriculum. However, providing Islamic based materials for English has become a concern for most of Islamic school teachers. Teachers point the lack of English language teaching materials in an Islamic school, there is consist of around textbook, limited vocabulary, lack of Islamic culture and discourse, low creativity among teachers and also technical in administrative.

The textbook is an essential part of teaching and learning. As the implementation of Kurikulum 2013, the government also developed a textbook to support the curriculum. However, the provided textbook is lack of contextual for Islamic School as it is developed to convey general school. Most of the English textbook provide general students daily life which is not the same as students in an Islamic school. The content is not supporting the Islamic school life in Islamic schools, there is a need to put themes which are supporting the goal of Islamic schools. The textbook is acceptable for a classroom activity in an Islamic school, however, to develop and to support Islamic schools' activity the general textbooks need to be improved in terms of themes and vocabulary.

Besides the context of the textbook, vocabulary in provided textbooks is not covering the activity in the Islamic Schools. The Islamic schools often have more activity outside the classroom than general school, they often do pray together, reciting the Quran together and some others related to devotion. Lack of suitable vocabulary, there are many vocabulary and instruction in Islamic life, for example, "wudhu" (ablution) never

Int. J. Eval. \& Res. Educ. Vol. 8, No. 2, June 2019: 286 - 292 
been included in a general English textbook. Teachers also do not have enough vocabulary related to Islamic terms.

Islamic discourse is often ignored in English language teaching. The fact that language and culture are as a single unit, teaching English is also teaching westerns' culture. Language and discourse are interrelated. The discourse is often innate within teaching material. The discourse is media to deliver culture, the western discourse commonly appears in general textbook. Considering the need to avoid westerns' culture, reducing the discourse and replace it with Islamic may help to deliver and instill cultural values for the students. The lack of cultural awareness within teachers makes the unintended culture spreads as the teachers teach the language.

The teacher may able to develop material from the internet. However, available internet resources are not well managed. The internet resource of text, multimedia is not maximized by teachers because teachers are attached to the provided textbook. The assumption that the textbook is well-prepared for curriculum make teachers take the textbook as main teaching materials and they often do not develop their own teaching materials. Teachers are also attached to administrative activities. Teachers need to make an administrative report of pre-teaching, teaching, evaluation and assessment. The numbers of administrative activities make them do not have the interest to develop their own teaching materials.

\subsection{How reading material should be developed?}

Considering the concept, policy and the suggestion from the teachers, it is necessary to develop English teaching materials based on Islamic values, real life experience and meaningful [7, 8, 15]. The developed material should cover the current curriculum applied in Indonesia. Indonesia has Kurikulum 2013 with a text-based approach for language teaching. This will lead the teachers, stakeholders, and school to enrich their discourse to fulfil the need of fuctional texbased language teaching in Kurikulum 2013. The textbased approach opens the opportunity for the teacher to administrate materials based on Islamic discourse to be formed in the functional text and also included in thematic teaching. The contents of the reading materials covered Islamic law (syari'ah), Islamic jurisprudence (fiqh), Islamic belief (aqidah), Islamic education, and Islamic history which can be included as themes $[9,16]$.

The materials also should consider integrated skill language teaching [19]. As research is intended for reading skill, it is necessary to integrate other skill into the activities. Reading skill need others skill to be evaluated, thus the materials and the activities from the developed materials should cover the integration of reading skill and other language skill as evaluation [10-12].

Culture should be considered in material development, the culture can be idea, habits, and artifact in physical form. As the Islamic values also act as daily life guideline, the integration is also practical in daily life and will become habits and culture. The culture represents how a Muslim act in their daily life, how to socialize among people. This can be integrated into teaching expression in language. Cultural integration can be also implemented in selecting an appropriate picture for the materials. Pictures are essential in language learning where they can describe and shows the proper use of certain and familiar vocabulary. General textbook often shows pictures of native English speaker, but it is often unappropriated for Islamic school in term of clothes usage $[11,20]$. The picture in general English textbook often exploits women's body to use short clothes which is not acceptable for Islamic school based on the akhlak idea. The use of an appropriate picture of human is one of some consideration to develop English teaching materials for Islamic schools.

The paradigm to help students to use English as much as they can, thus the teaching approach should make students as the subject of language learning. The students centered design need to be redesigned to be applied. Students centered design in English language teaching will provide opportunities to apply their English. This will help them to gain confidence to use English which often most of the students are a worry to produce English. Teacher may develop a procedure text for teaching language features for imperative sentences, adverb of sequence based on how to do Wudhu' or ablution. English in Kurikulum 2013 also uses a thematic teaching approach, which may help contextualization of language use. Narrative text based on Islam characters such as Ahmad Dahlan from the Muhammadiyah, a notable Islamic organization in Indonesia, or Muhammad bin Mūsā al-Khawārizmī the one who proposed Al-Jabr, most notable concept in math, and other characters which can be developed to be a narrative text. This text will also motivate students to know great figures in Islam history, the one who had a distinguished effect in human history and shows that Islam is not inferior in contribution towards the development of global knowledge. Besides the textbased, language teaching should be communicative, which means the text should be meaning full in the context of an Islamic school. The similar pattern can be adopted for descriptive text, recount text, and report text in Junior high school students' level.

Need analysis of Islamic-based English reading material for the Muhammadiyah ... (Septian Dwi Cahyo) 


\section{CONCLUSION}

As the emerging of Islamic education and character education concept in Indonesia, an alternative English language teaching material is needed as an alternative to reduce the conflict between English as a representation of western values and Islamic value. Islamic-based reading material for current education should also consider the concept of integrated skill teaching, meaningful. This intention is supported by Majelis dikdasmen muhammadiyah DIY, as they encourage their school to apply school-based management thus the potential of English teachers to develop their genuine material for their students. However, the standardized materials for Islamic based English language teaching material has not been developed. Further research on material development of Islamic based English language teaching need to be conducted.

\section{REFERENCES}

[1] Wiryanto, W. "The islamization of human resource management textbook for higher education in indonesia through al-faruqi’s theory 1," International Journal of Islamic Studies, vol 3(1), pp. 121-160, 2016.

[2] Irwansyah, D. "Teaching English at Indonesian Islamic Higher Education: An Epistemological Perspective," DINAMIKA ILMU, vol 18(1), pp. 1-14, 2018. https://doi.org/dx.doi.org/10.21093/di.v18i1.1120

[3] Baytiyeh, H. "Have globalisation's influences on education contributed to the recent rise of Islamic extremism?," Globalisation, Societies and Education, pp. 1-13. 2018. https://doi.org/10.1080/14767724.2018.1456321

[4] Aqsha, M., Ramlee, L., Abdullah, M., and Lampoh, A. "Integrated Islamic Education in Brunei Darussalam: Philosophical Issues and Challenges," Journal of Islamic and Arabic Education, vol. 1(2), pp. 51-60, 2009.

[5] Misnistry of Education of Republic of Indonesia. Law No. 22 of 2006 (2006). Indonesia: KEMENDIKNAS.

[6] Tomlinson, B. "Principles and Procedures of Materials Development for Language Learning 3 Proposals for Principled Approaches to the Development of English language Teaching Materials (1995)," 2010.

[7] Abdollahzadeh, Esmaeel. Baniasad, Somayeh. "Ideologies in the Imported English Textbooks: EFL learners and Teachers' Awareness and Attitude," Journal of English language teaching and Learning. Year 53 No. 217, 2010.

[8] Khosravani, M., Khosravani, M., and Khorashadyzadeh, A. "Analyzing the effects of Iranian EFL textbooks on developing learners' life skills," English Language Teaching, vol. 7(6), pp. 54-67, 2014. https://doi.org/10.5539/English language teaching. v7n6p54

[9] Muhsinin, M., Saleh, M., Rukmini, D., and Sofwan, A. "The Need to Develop English for Specific Purposes (ESP) Reading Syllabus for Students of Islamic Education Department - Islamic Higher Education Institution," Journal of Foreign Languages, Cultures and Civilizations, vol. 5(1), pp. 24-33, 2017. https://doi.org/10.15640/jflcc.v5n1a4

[10] Umam, C. "Maintaining Islamic Values in English language teaching in Indonesian Pesantrens," Didaktika Religia, vol. 2(1), pp. 227-242, 2014.

[11] Faridi, A., Bahri, S., and Nurmasitah, S. "The Problems of Applying Student Centered Syllabus of English in Vocational High Schools in Kendal Regency," English Language Teaching, vol. 9(8), pp. 231, 2016. https://doi.org/10.5539/English language teaching.v9n8p231

[12] Amri, M., Tahir, S. Z. A. Bin, and Ahmad, S. "The Implementation of Islamic Teaching in Multiculturalism Society: A Case Study at Pesantren Schools in Indonesia," Asian Social Science, vol. 13(6), pp. 125, 2017. https://doi.org/10.5539/ass.v13n6p125

[13] Sunengsih, N., and Fahrurrozi, A. "Learners' Language Needs Analysis of English Subject in Azkia Integrated Islamic Primary School," IJEE (Indonesian Journal of English Education), vol. 2(1), pp. 89-103, 2016. https://doi.org/10.15408/ijee.v2i1.1483

[14] Ulum, Ö. G. "A needs analysis study for preparatory class English language teaching students." European Journal of English Language Teaching, vol. 1(1), pp. 14-29, 2015.

[15] Rohmah, Z. "Efl Materials in Madrasah Tsanawiyah: What Do They Really Need?," TEFLIN Journal, vol. 20(1), pp. 104-117, 2015. https://doi.org/10.15639/TEFLINJOURNAL.V20I1/104-117

[16] Qamariah, Z. "Developing Islamic English Instructional Materials Based on School-Based," Journal on English as a Foreign Language, vol. 5(2), pp. 99-112, 2015.

[17] Moiinvaziri, M. "Students' Voice: A Needs Analysis of University General English Course in Iran," GEMA Online ${ }^{\circledR}$ Journal of Language Studies, vol. 14 (February), pp. https://doi.org/10.17576/GEMA-2014-1401-05, 2014

[18] Bakar, A., and Siregar, A. "Islamisasi ilmu pengetahuan," Fikrah, vol. 6(2), pp. 91-100. 2004.

[19] L. Plakans, J.-T. Liao, and F. Wang, "Integrated assessment research: Writing-into-reading," Language Teaching, vol. 51(3), pp. 430-434, 2018.

[20] Ariyanto, Sugeng. "A portrait of gender bias in the prescribed Indonesian ELT textbook for junior high school students," Sexuality \& Culture, 2018, 22.4: 1054-1076.

Int. J. Eval. \& Res. Educ. Vol. 8, No. 2, June 2019: 286 - 292 